\title{
Decadal changes in the structure of Cymodocea nodosa seagrass meadows: Natural vs. human influences
}

\author{
Fernando Tuya ${ }^{\mathrm{a}, *}$, Luís Ribeiro-Leite ${ }^{\mathrm{b}}$, Noelia Arto-Cuesta ${ }^{\mathrm{b}}$, Josep Coca ${ }^{\mathrm{c}}$, Ricardo Haroun ${ }^{\mathrm{a}}$, \\ Fernando Espino $^{a}$ \\ a BIOGES, Universidad de Las Palmas de Gran Canaria, 35017 Las Palmas, Canary Islands, Spain \\ b elittoral S.L.N.E, Estudios de ingeniería costera y oceanográfica, Edif. Polivalente II - Parque Científico Tecnológico, Oficinas 4 y 19, 35017 Las Palmas, \\ Canary Islands, Spain \\ ${ }^{\mathrm{c}}$ ROC-IUSIANI, Universidad de Las Palmas de Gran Canaria, 35017 Canary Islands, Spain
}

\section{A R T I C L E I N F O}

\section{Article history:}

Received 4 October 2013

Accepted 27 November 2013

Available online xxx

\section{Keywords:}

seagrass

water quality

decline

human-mediated impact

Canary Islands

\begin{abstract}
A B S T R A C T
Seagrass meadows are deteriorating worldwide. However, numerous declines are still unreported, which avoid accurate evaluations of seagrass global trends. This is particularly relevant for the western African coast and nearby oceanic archipelagos in the eastern Atlantic. The seagrass Cymodocea nodosa is an 'ecological engineer' on shallow soft bottoms of the Canary Islands. A comparative decadal study was conducted in $21 \mathrm{C}$. nodosa seagrass meadows at Gran Canaria Island to compare the structure (shoot density, leaf length and cover) between 2003 and 2012. Overall, 11 meadows exhibited a severe regression, while 10 remained relatively stable. During this period, natural influences (sea surface temperature, Chlorophyll-a concentration and PAR light, as well as the number of storm episodes detaching seagrasses) had a low predictive power on temporal patterns in seagrass structure. In contrast, proximity from a range of human-mediated influences (e.g. the number of outfalls and ports) seem to be related to the loss of seagrass; the rate of seagrass erosion between 2003 and 2012 was significantly predicted by the number of human-mediated impacts around each meadow. This result highlights promoting management actions to conserve meadows of $C$. nodosa at the study region through efficient management of local impacts.
\end{abstract}

(c) 2013 Elsevier Ltd. All rights reserved.

\section{Introduction}

Seagrasses constitute a key habitat on shallow soft bottoms worldwide, where they profoundly influence the physical, chemical, and biological environments - acting as 'ecological engineers' (Wright and Jones, 2006) - providing numerous 'goods and ecological services' to humans. Seagrasses, in fact, alter water flow, nutrient cycling, and food web structure, stabilize sediments and produce large quantities of organic carbon (Hemminga and Duarte, 2000), some of which is exported to other coastal and deep-sea habitats, hence providing an important supply of organic matter. Moreover, much of the organic carbon produced is buried in sediments, promoting the $\mathrm{C}$ sequestration in the biosphere (Duarte et al., 2005).

The location of seagrasses on shallow waters, and their vulnerability to altering environmental conditions, exposes

\footnotetext{
* Corresponding author.

E-mail address: ftuya@yahoo.es (F. Tuya).
}

seagrasses to different types of human-induced disturbances, which frequently leads to habitat loss and eventually local/ regional extirpation. In fact, large-scale seagrass losses have been reported in many coastal areas, mainly due to intense humanrelated activities, what has caused a worldwide declining trend (Orth et al., 2006; Duarte et al., 2008; Hughes et al., 2009; Waycott et al., 2009; Short et al., 2011). Importantly, when seagrasses disappear, the 'goods and ecological services' they provide are eroded, affecting the coastal ecosystem (i.e. loss of water quality, reduction of primary and secondary production, biodiversity, artisanal fisheries decline, etc.). The conservation of these valuable habitats must be a priority in any environmental policy programme. There is, however, sparse information on seagrass distribution and abundance patterns from most coastal areas of the world and so many losses remain unreported, leading to inaccurate evaluations of seagrass global trends (Duarte et al., 2008). This is particularly relevant for the western African coast (Cunha and Araújo, 2009) and nearby oceanic archipelagos.

Cymodocea nodosa (Ucria) Ascherson is a seagrass distributed across the Mediterranean Sea and adjacent eastern Atlantic

0272-7714/\$ - see front matter (c) 2013 Elsevier Ltd. All rights reserved. http://dx.doi.org/10.1016/j.ecss.2013.11.026 
coasts, including the Macaronesian archipelagos of Madeira and the Canaries, all the way down to Senegal in the western African coast (Alberto et al., 2006; Mascaró et al., 2009; Cunha and Araújo, 2009). Meadows constituted by C. nodosa are often the dominant vegetated communities on shallow soft substrates of the Canaries (Reyes et al., 1995a; Pavón-Salas et al., 2000; Barberá et al., 2005; Tuya et al., 2013a), where they support a high number of algal species (Reyes and Sansón, 1997), providing food and shelter for diverse invertebrates and fish assemblages (Tuya et al., 2001, 2006; Espino et al., 2011a). These meadows are generally located along the eastern and southern coasts of the islands, sheltered from the dominant oceanic swells from the north and north-west, forming extensive, but often fragmented, subtidal meadows. At within-meadow scales, high-energy swells may remove seagrass vegetative fragments, particularly in winter, deteriorating seagrass vitality. In the Canary Islands, C. nodosa shows a clear seasonal pattern, with a summer peak in shoot density and biomass (Reyes et al., 1995a, 1995b; Tuya et al., 2006), similar to what has been observed in the Mediterranean Sea (Terrados and Ros, 1993).

Recently, Short et al. (2011) considered the population trend of Cymodocea nodosa as 'stable' along the temperate North Atlantic and Mediterranean, and categorized C. nodosa - according to criteria from the IUCN Red List of Threatened Species - as 'least concern'. In the Canary Islands, there is scarce data to support the conservation status of $C$. nodosa; indeed, the Canarian Autonomous Government recently enacted a new environmental law, which reduced its protection status (BOC $n^{\circ} 112$, Law 4/2010 of the Canarian Catalogue of Protected Species). This seagrass is exclusively protected within marine protected areas, e.g. 'Special Areas of Conservation' under the EU 'Natura 2000' network. A recent study found a severe decline in the presence of this seagrass at 5 meadows from Gran Canaria Island when data from 1995 was compared with 2011 (Tuya et al., 2013b). However, it is essential to encompass a wide range of meadows under distinct environmental scenarios to adequately assess temporal trends of any seagrass (Montefalcone et al., 2007), including estimations of the effects of natural disturbances (Boudouresque et al., 2009), to support proper management actions by coastal resources managers.

In this study, we (i) compared the structure of Cymodocea nodosa seagrass, through 3 key seagrass structural descriptors: seagrass shoot density, leaf length and cover, at 21 meadows along the coastal perimeter of Gran Canaria Island between summer 2003 and summer 2012. To determine whether natural and/or human influences may have contributed to explain temporal trends from 2003 to 2012, we (ii) analysed temporal patterns in natural influences, here Sea Surface Temperature (SST), surface Chlorophyll-a concentration (Chl-a) and Photosynthetically Active Radiation (PAR) above seagrass canopies, as well as wave-induced disturbances (number of storms detaching seagrasses), and (iii) estimated whether proximity from number and types of human impacts, in conjunction with natural influences, explained rates of change in the structure (shoot density, leaf length and cover) of meadows between 2003 and 2012. The combination of these approaches allowed us to discriminate whether natural and/or human influences may explain temporal trends at the island scale between 2003 and 2012.

\section{Materials and methods}

\subsection{Study area and seagrass sampling}

Twenty one seagrass meadows were sampled across the entire distribution area of Cymodocea nodosa in Gran Canaria Island $\left(27^{\circ} 58^{\prime} \mathrm{N}, 1^{\circ} 36^{\prime} \mathrm{W}\right.$, Fig. 1, Table 1; Espino et al., 2003). Each meadow was, at least, between 0.5 and $10 \mathrm{~km}$ apart from the adjacent meadow, so we encompassed all range of conditions across the island perimeter where $C$. nodosa is present. At each meadow, two sites were randomly selected during the summer 2003 and again in summer 2012 (hereafter 2003 vs. 2012). On each sampling time, three seagrass structural descriptors were assessed in situ through SCUBA divers at each site: (1) shoot density (by counting seagrass shoots in $n=6,25 \times 25 \mathrm{~cm}$, quadrats), (2) leaf length (by measuring average leaf length in 20 shoots randomly selected) and (3) seagrass cover (by registering the distance under a $1 \mathrm{~cm} \times 25 \mathrm{~m}$ flexible line transect covered by $C$. nodosa to the nearest $\mathrm{cm}$, and subsequent calculation of percentage cover, $n=6$ ). It is worth noting that this descriptor does not refer to the total area occupied by each meadow at large-scales, but to a local-scale measure of seagrass fragmentation. These descriptors have been previously used at the study region to describe the physical structure of $C$. nodosa meadows (Reyes et al., 1995a,b; Tuya et al., 2002; Espino et al., 2003; Barberá et al., 2005; Tuya et al., 2006; Espino et al., 2011a, 2011b). All measurements were standardized to $\mathrm{m}^{2}$ to facilitate comparisons with other studies.

\subsection{Natural influences: satellite-derived data}

Environmental data (SST, Chl- $a$ and surface PAR) were acquired from monthly level-3 standard mapped image (SMI) files derived from the Aqua MODIS (MODerate-resolution Imaging Spectroradiometer) sensor, available on NASA's Ocean Color Web (oceancolor.gsfc.nasa.gov/). Satellite-derived data for SST correlate with temperature above the bottom on nearshore habitats, typically at $<20 \mathrm{~m}$ depth (Smale and Wernberg, 2009). The SST4 product was selected for SST data, which corresponds to SST derived from near infrared bands detected by the MODIS sensor during nighttime. Monthly data files in HDF format were selected and then extracted from pixels that encompassed each seagrass meadow as shown in Fig. 1 . The period of satellite data extraction covered from January 2003 to December 2012. By taking into account the depth ( $z$, Table 1$)$ and the surface $\operatorname{PAR}\left(I_{0}\right)$ derived from satellite imagery, we calculated the PAR above seagrass canopies $\left(I_{z}\right)$ at each meadow via the equation: $I_{z}=I_{o} e^{-k z}$. We assumed an average $k(\mathrm{PAR})$ light attenuation coefficient of 0.15 for the study region; this value was previously reported for the water column above a seagrass meadow in the Canary Islands (Tuya et al., 2002). Values of $k$ (PAR) may have been alternatively derived from remote sensing using the $K(490)$ product data for offshore waters (Morel et al., 2007). However, remote sensing derived $k$ (PAR) is not suitable for coastal waters. Despite this approach ignores among-seagrass fluctuations in $k$ (PAR), it provides a proxy to light intensity at each seagrass. Means, variances and coefficients of variation (CV) for each environmental variable at each seagrass meadow were calculated from January 2003 to December 2012 for further statistical analyses and graphical purposes.

\subsection{Natural influences: temporal trends in swell-induced disturbances}

To describe the wave climate, we derived data (wave height and period) from 2 WANA datasets from the south-west and south-east off Gran Canaria Island (WANA-1017010 and WANA-1019011, respectively, Fig. 1; hereafter WANA-10 and WANA-11, respectively), freely provided by the national 'Puertos del Estado' port authority (www.puertos.es). To define a storm episode as that event potentially detaching Cymodocea nodosa plants from the bottom, we took advantage of two previous studies that determined the tolerance of $C$. nodosa to wave-induced (swell) orbital velocities $\left(v_{o}\right)$. According to Infantes et al. (2011), plants from the Mediterranean 

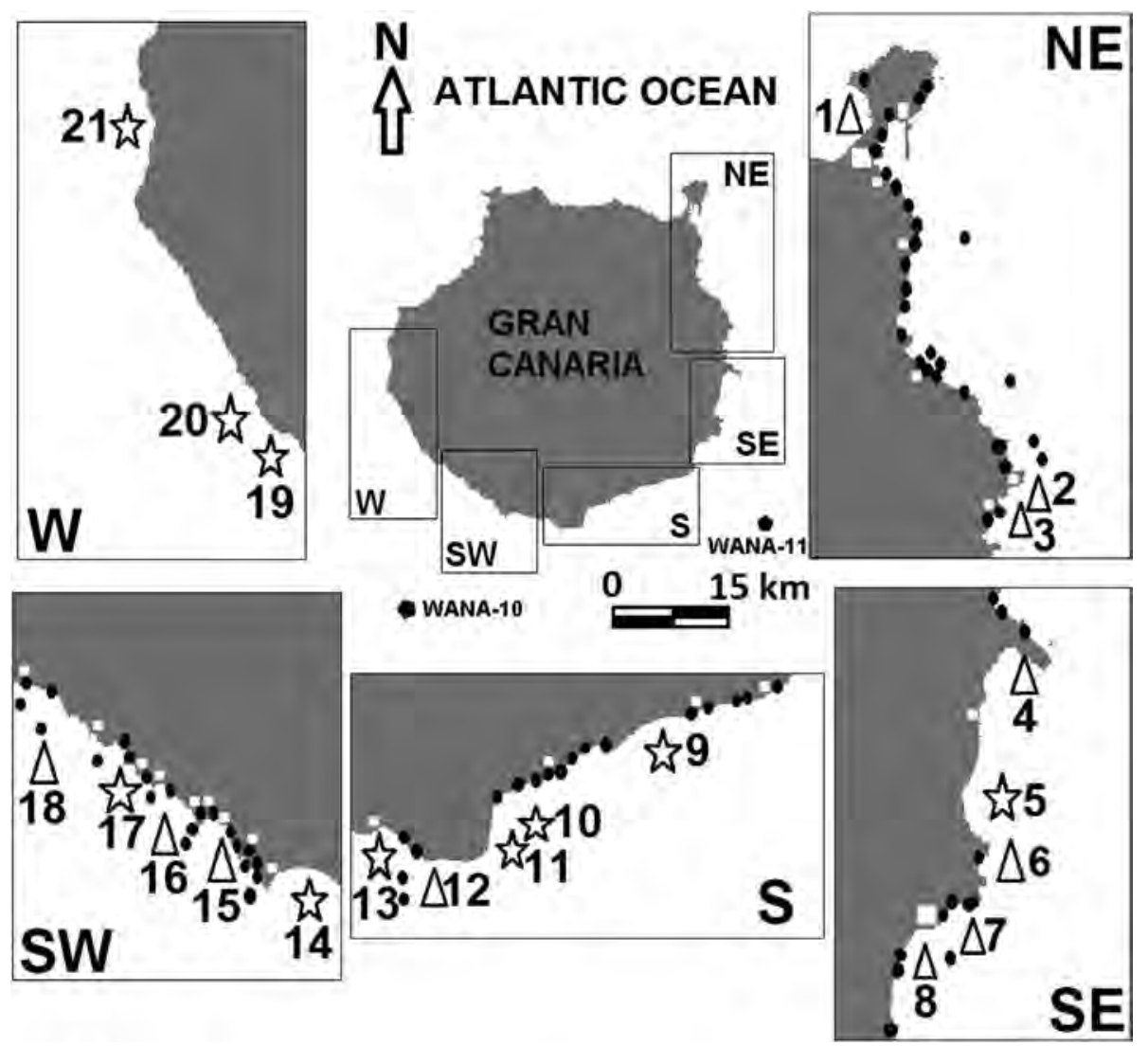

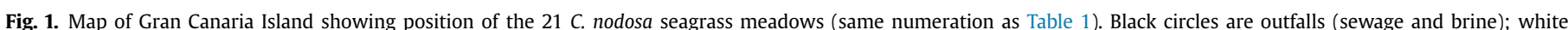

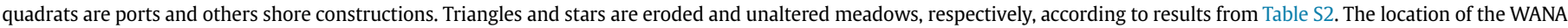
wave datasets (WANA-10 and WANA-11) is also included.

can cope with $v_{o}$ up to $39 \mathrm{~cm} \mathrm{~s}^{-1}$, while Cabaço et al. (2010) considered a $v_{o}$ threshold of $60 \mathrm{~cm} \mathrm{~s}^{-1}$ for plants from the Atlantic southern Iberian Peninsula. In our study, we established a 'rule of thumb' of $v_{o}=50 \mathrm{~cm} \mathrm{~s}^{-1}$; a storm episode was then defined as those 'sea states' creating $v_{o} \geq 50 \mathrm{~cm} \mathrm{~s}^{-1}$. Through the implementation of the linear wave theory from deep to intermediate waters, a wave propagation model was created to define, for the range of depths

Table 1

Location, depth and area of Cymodocea nodosa meadows at 2003 (clockwise from north to west) across Gran Canaria Island.

\begin{tabular}{lllcl}
\hline Meadow & UTM x & UTM y & Depth $(\mathrm{m})$ & Area $\left(\mathrm{m}^{2}\right)$ \\
\hline 1. Las Canteras & 28R 457334 & 3113261 & 3 & 3437 \\
2. Taliarte & 28R 463640 & 3096008 & 8 & 6026 \\
3. Salinetas & 28R 463076 & 3095352 & 11 & 4065.55 \\
4. Gando & 28R 463189 & 3089801 & 10 & $93,596.7$ \\
5. Burrero-Vargas & 28R 462130 & 3087725 & 10 & 226,493 \\
6. El Cabrón & 28R 462204 & 3082857 & 10 & $101,638.75$ \\
7. Arinaga & 28R 460944 & 3080980 & 9 & 261,550 \\
8. Formas & 28R 459275 & 3080107 & 9 & $255,324.75$ \\
9. El Cardón & 28R 451496 & 3073756 & 8 & $41,812.35$ \\
10. El Cochino & 28R 444853 & 3070828 & 10 & $15,264.1$ \\
11. El Inglés & 28R 444360 & 3069479 & 9 & $252,986.5$ \\
12. Maspalomas & 28R 441478 & 3067446 & 10 & $2,372,885.5$ \\
13. Meloneras-Pasito & 28R 439393 & 3068620 & 12 & $46,409.5$ \\
14. Santa Agueda & 28R 434031 & 3070028 & 10 & 24,741 \\
15. Marañuelas-Balito & 28R 431955 & 3071358 & 12 & $26,517.35$ \\
16. Puerto Rico & 28R 430234 & 3072775 & 15 & 2953.5 \\
17. Amadores & 28R 428513 & 3074105 & 10 & $83,616.75$ \\
18. Taurito & 28R 425596 & 3076613 & 12 & $122,489.1$ \\
19. Veneguera 1 & 28R 421364 & 3081040 & 10 & $19,683.4$ \\
20. Veneguera 2 & 28R 421091 & 3080952 & 12 & $32,979.5$ \\
21. Güi Güi & 28R 418245 & 3090698 & 15 & $179,926.2$ \\
\hline Area data are from Espinas
\end{tabular}

Area data are from Espino et al., 2003. where $C$. nodosa typically occur (Table 1 ), the period and wave height (sea states) capable of generating $v_{0} \geq 50 \mathrm{~cm} \mathrm{~s}^{-1}$. Sea states encompassed wave data (wave period and height) pooled through 3 consecutive hours; when 10 successive sea states had a $v_{o}<50 \mathrm{~cm} \mathrm{~s}^{-1}$, episodes were considered as independent. The wave climate of seagrass meadows 2 to 11 (Table 1, Fig. 1) were characterized by the WANA-11 dataset, which correspond to the south-east face off Gran Canaria; the wave climate of seagrass meadows 12 to 21 (Table 1, Fig. 1) was characterized through the WANA-10 dataset, which correspond to the south-west face off Gran Canaria. The wave climate of meadow 1 , the only meadow located in the north coast (Table 1, Fig. 1) and so out of the reach of the two WANA datasets, was not accounted, and so was rule out. The number of storm episodes was then calculated for each year between 2003 and 2012, separately for each wave dataset (WANA-10 and WANA-11) and the range of depths were meadows are found (Table 1). Annual means, variances and their corresponding coefficients of variation (CV) were then calculated for each seagrass meadow for further statistical analyses. It is worth noting, however, that this approach ignores that topographic elements of the coast may alter the Hs of swells at each seagrass meadow, and that all storms were considered to be equally severe. Despite these two limitations, this method provides an overall assessment on whether the frequency of storms has increased between 2003 and 2012.

\subsection{Determination of anthropogenic-induced impacts}

To explain temporal changes in seagrass structural attributes between 2003 and 2012, we identified the number of putative human impacts over seagrass meadows, e.g. outfalls, commercial 
ports and other coastal constructions (i.e. marinas, breakwaters, piers, artificial beaches, i.e. civil engineering structures), off-shore fish farms and run-off points within a 500 m-radius up and down each seagrass meadow, using the available information provided by the Geographic Information System (GIS) of the Canary Islands Autonomous Government (www.idecan.grafcan.es/idecan/, Table S1). The ' $500 \mathrm{~m}$-threshold' was somehow a 'rule of thumb', though some evidence has indicated this distance as a 'security buffer' of non-affection over seagrasses (Pergent-Martini et al., 2006; Cabaço et al., 2008).

\subsection{Statistical analysis}

Temporal differences between years (hereafter 2003 vs. 2012) and meadows were tested by 3-way, permutation-based, ANOVAs, including the factors: 'Year' (fixed factor), 'Meadow' (random factor and orthogonal to 'Year') and 'Site' (random factor nested within both 'Year' and 'Meadow'). Pairwise comparisons, using 999 permutations, resolved differences between years separately for each meadow (significant 'Year $\times$ Meadow' interactions). Permutational ANOVA uses permutations to calculate $P$ values (Anderson, 2001); this was preferable because the data were over-dispersed and contained many zeros for some meadows in 2012. The test statistic (pseudo- $F$ ) is an analogue of the univariate Fisher's $F$ ratio; in the univariate context the two are identical when using Euclidean distance as the dissimilarity measure (Anderson, 2001). Multiple linear regression models tested whether the $\mathrm{CV}$ of natural influences (SST, Chl- $a$ and PAR, as well as the number of storms) from 2003 to 2012 and the number and type of human-related impacts within a $500 \mathrm{~m}-$ radius up and down each seagrass meadow (Table S1) predicted changes in seagrass shoot density, leaf length and cover between 2003 and 2012. All analyses were based on a 'forward' selection procedure; the Akaike Information Criterion (AIC) routine was implemented to retain those predictor variables with the larger explanatory power as a parsimony criterion (the smaller the value the better the model, Anderson and Legendre, 1999), as a result of collinearity among predictor variables. The contribution of each independent variable to each model was described with partial $r^{2}$ values. We also tested, by means of a simple linear regression, whether the total number of human affections (hereafter 'total number of impacts') within a 500 m-radius up and down each seagrass meadow affected overall changes in seagrass shoot density, leaf length and cover between 2003 and 2012.

\section{Results}

\subsection{Temporal trends in seagrass structure}

At the island-scale, the shoot density, leaf length and cover of Cymodocea nodosa exhibited an overall decrease of $\sim 2,1.9$ and 1.6 times, respectively, between 2003 and 2012 (Fig. 2; 3-way ANOVAs: 'Year', $P<0.001$, Table 2). Importantly, however, differences in the structural descriptors between 2003 and 2012 were not consistent among meadows (' $Y \times M$ ', $P<0.001$, Table 2 ). Pairwise comparisons between years (2003 vs. 2012) for each meadow showed significant reductions for all descriptors at 8 meadows (Taliarte, Salinetas, Gando, Arinaga, Formas, Maspalomas, Puerto Rico and Taurito) (Table S2). In contrast, 3 meadows did not show any significant difference at all (Santa Agueda, Veneguera 2, and Güi Güi), while five meadows (Burrero-Vargas, El Inglés, Meloneras-Pasito, Amadores, and Venegura 1) solely showed a decrease for leaf length (Table S2). Three meadows showed significant decreases in shoot density and leaf length (Las Canteras, El Cabrón, Marañuelas-Balito, Table S2). Exclusively one meadow (El Cochino) experienced an increase in cover, while another meadow (El Cardón) significantly
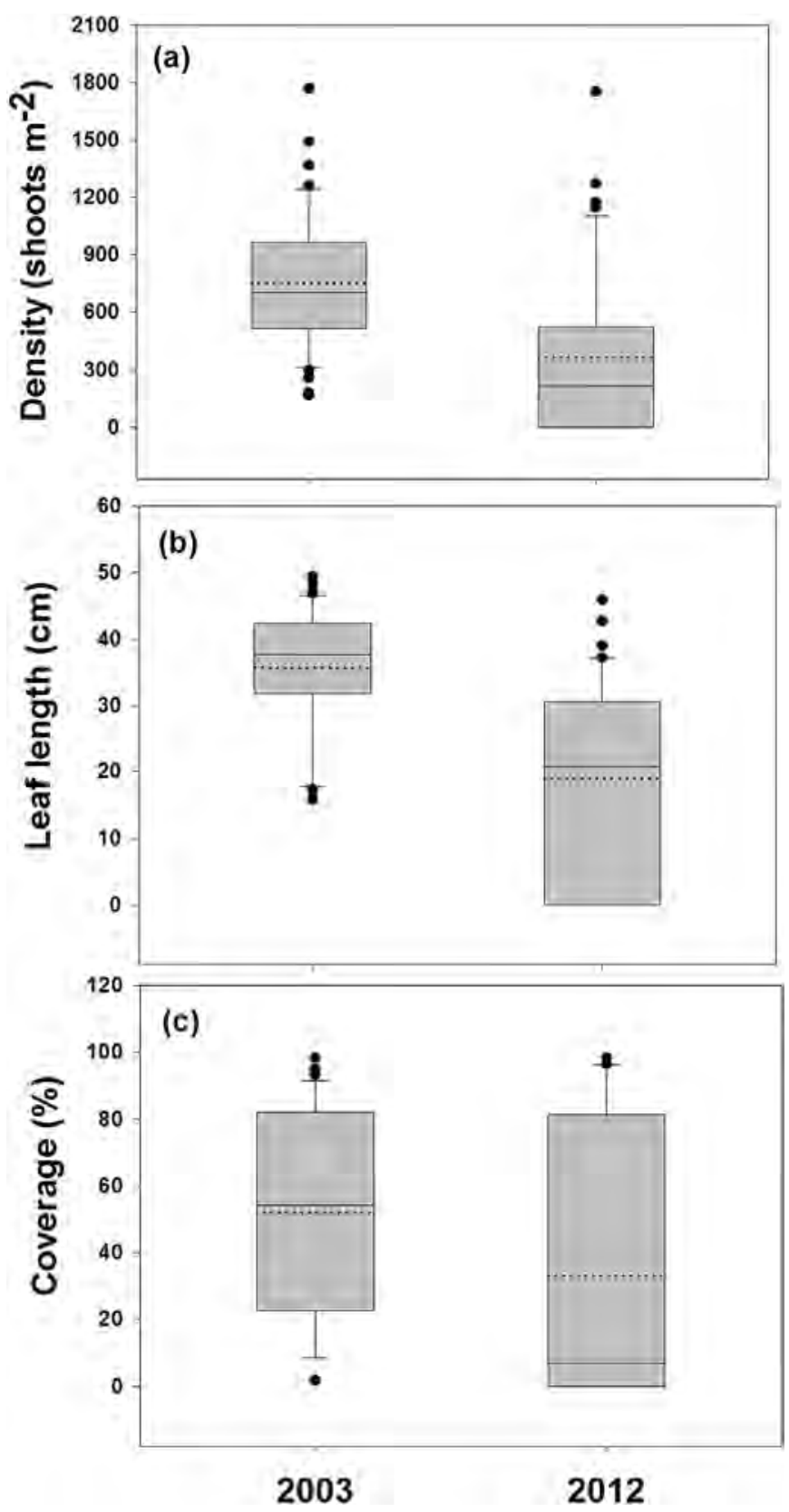

Fig. 2. Differences in seagrass (a) shoot density (shoots $\mathrm{m}^{-2}$ ), (b) leaf length (cm), and (c) cover (\%) of C. nodosa at the island-scale between 2003 and 2012. Dotted lines are means and solid lines are medians.

increased shoot density, but declined in leaf length (Table S2). The integration of this biological information qualitatively suggests that 11 meadows showed an overall decline in the abundance of C. nodosa from 2003 to 2012 (i.e. 2 or 3 structural descriptors suffered a significant decay), while 10 can be considered as stable, despite some decays in, at least, one structural descriptor (Fig. 1).

\subsection{Temporal trends in natural influences}

For all meadows, SST typically ranged between $18{ }^{\circ} \mathrm{C}$ (winter) and $24^{\circ}$ (summer) (Fig. 3a), Chl- $a$ between 0.05 and $0.25 \mathrm{mg} \mathrm{m}^{-3}$ (Fig. 3b) and PAR between 5 and $40 \mathrm{E} \mathrm{m}^{-2} \mathrm{~d}^{-1}$ (Fig. 3c). The number of storms per year was typically larger for meadows located in the east and south-east of Gran Canaria (meadows 2-11, Fig. 4) than 
Table 2

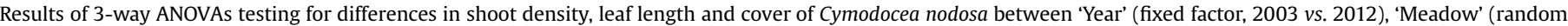
factor) and 'Site' (random factor nested within 'Year' and 'Meadow')

\begin{tabular}{|c|c|c|c|c|c|c|c|c|c|c|}
\hline \multirow[t]{2}{*}{ Source of variation } & \multirow[b]{2}{*}{$\mathrm{DF}$} & \multicolumn{3}{|c|}{ Shoot density } & \multicolumn{3}{|l|}{ Leaf length } & \multicolumn{3}{|l|}{ Cover } \\
\hline & & MS & $F$ & $P$ & MS & $F$ & $P$ & MS & $F$ & $P$ \\
\hline Year, $Y$ & 1 & 1166.955 & 16.947 & 0.0004 & 1087.778 & 80.659 & 0.0002 & 779.050 & 8.772 & 0.0086 \\
\hline Meadow, $M$ & 20 & 69.394 & 9.733 & 0.0002 & 24.471 & 12.125 & 0.0002 & 179.304 & 14.033 & 0.0002 \\
\hline Site $(Y \times M)$ & 42 & 7.129 & 13.345 & 0.0002 & 2.0181 & 1.280 & 0.1238 & 12.777 & 17.014 & 0.0002 \\
\hline$Y \times M$ & 20 & 68.859 & 9.658 & 0.0002 & 13.486 & 6.682 & 0.0002 & 88.811 & 6.950 & 0.0002 \\
\hline Residual & 420 & 0.534 & & & 1.576 & & & 0.751 & & \\
\hline
\end{tabular}

meadows located in the west and south-west of the island (meadows 12-21, Fig. 4).

\subsection{Human influences as driver of temporal trends in seagrass structure}

For the 3 seagrass structural descriptors, the best models provided by the AIC routine mostly included human-related predictor variables (Table 3). At the island-scale, changes in seagrass shoot density and leaf length between 2003 and 2012 were majorly predicted by the number of outfalls within a $500 \mathrm{~m}$-radius up and down each seagrass meadows ( $\mathrm{ca}$. $23 \%$ and $33 \%$ of the total variability, respectively, Table 3 ). Changes in seagrass cover between 2003 and 2012 were majorly predicted by the number of ports within a $500 \mathrm{~m}$ radius up and down each seagrass meadows (ca. 19\% of the total variability, Table 3). The number of coastal run-off points a)

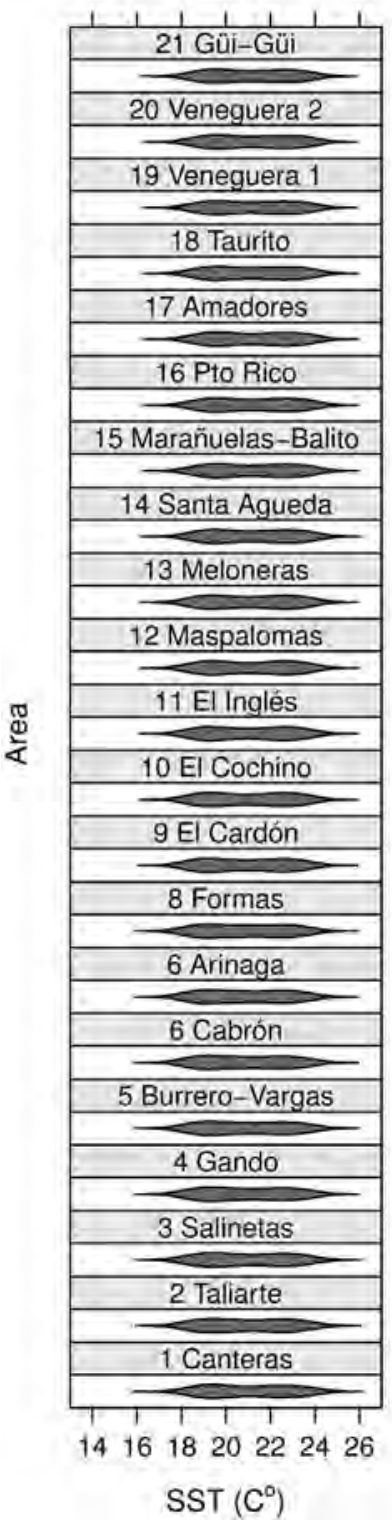

b)

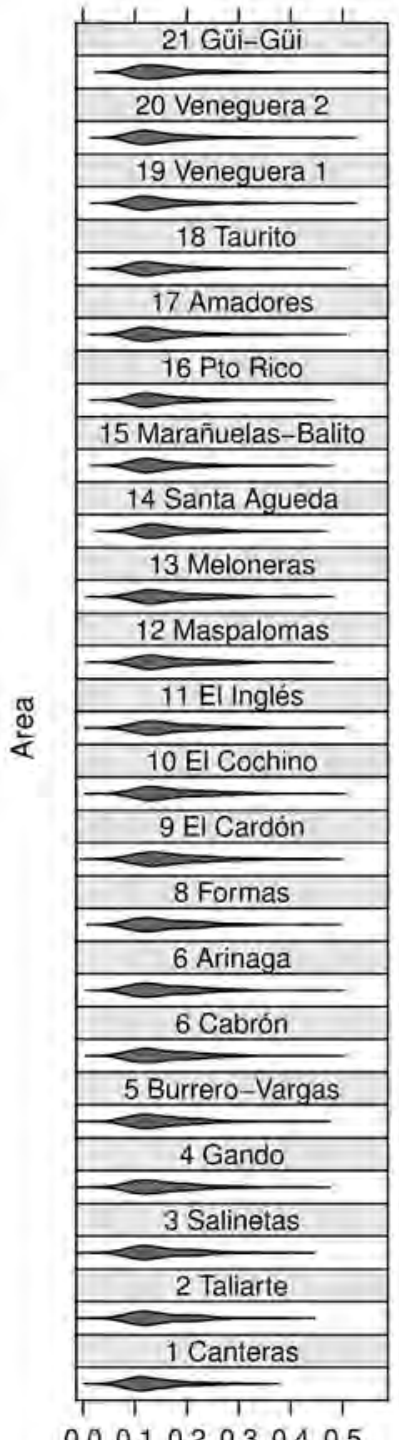

0.00 .10 .20 .30 .40 .5

[Chlorophyll-a] $\left(\mathrm{mg}^{*} \mathrm{~m}^{-3}\right)$ c)

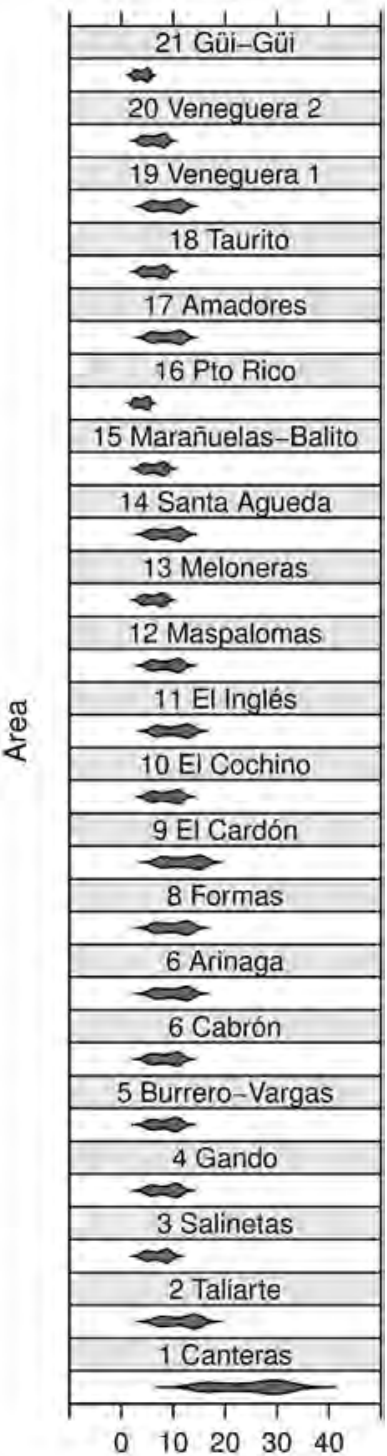

PAR (Einstein $/ \mathrm{m}^{2 *}$ dia)

Fig. 3. Patterns of environmental variables at each seagrass meadow off Gran Canaria Island between 2003 and 2012: (a) SST, (b) surface Chl- $a$ concentration and (c) PAR. 


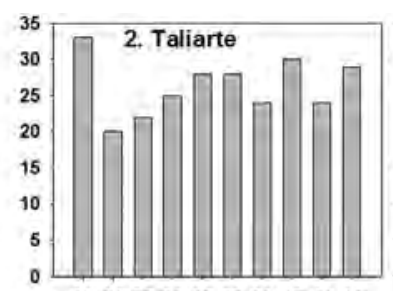

03040506070809101112

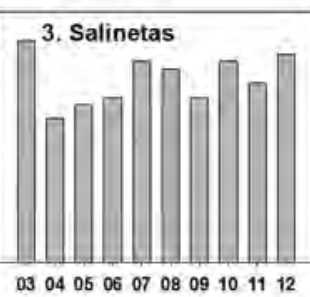

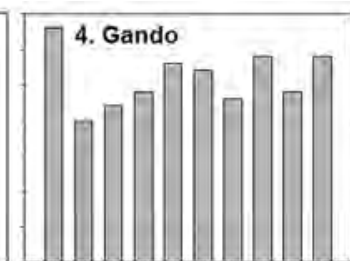

03040506070809101112

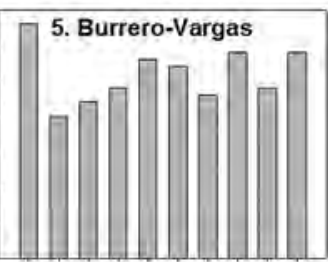

$030405060708 \quad 091011 \quad 12$

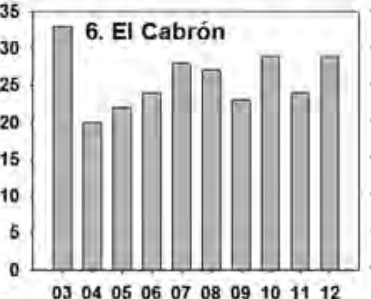

7. Arinaga

11. El Inglés

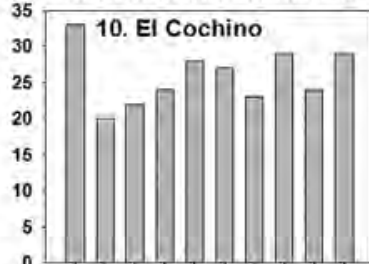

03040506070809101112

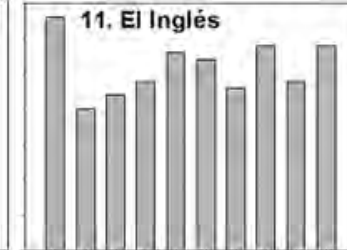

05 $040506 \quad 07 \quad 08091011 \quad 12$

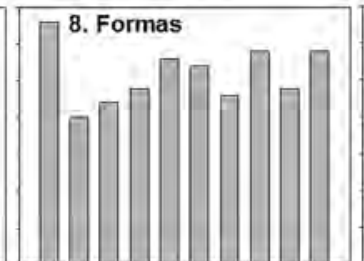

03040506070809101112

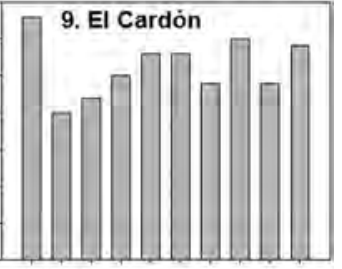

$03040506 \quad 070809101112$

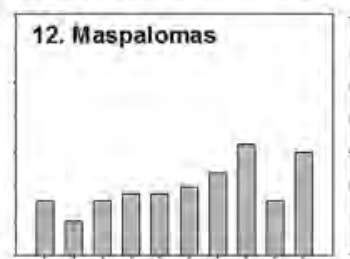

03040506070809101112

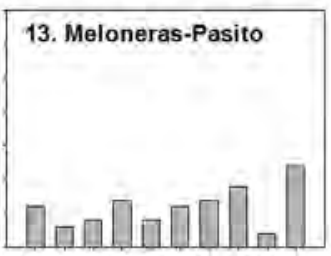

03040506070809101112
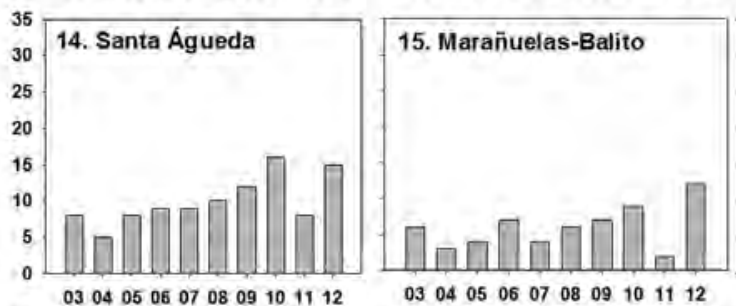

16. Puerto Rico

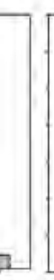

03040506070809101112

19. Veneguera 1

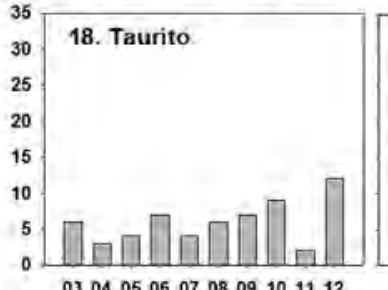

19.

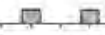

03040506070809101112

03040506070809101112

03040506070809101112

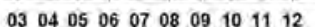

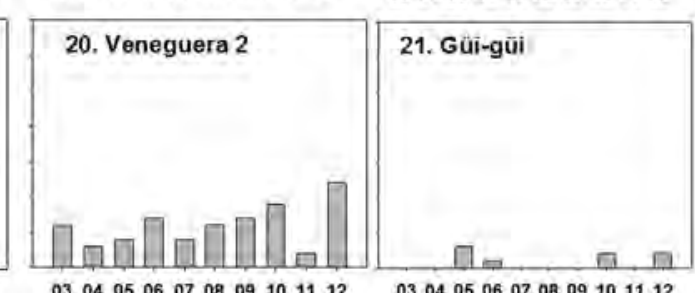

Fig. 4. Number of storms per year potentially detaching seagrasses for each meadow.

additionally contributed to explain a ca. $14 \%$ of the total variation in seagrass shoots density between 2003 and 2012 (Table 3), and the number of fish farms within a 500 m-radius up and down each seagrass meadows accounted for a $\mathrm{ca}$. $7 \%$ of the total variation in leaf length between 2003 and 2012 (Table 3). Variation in PAR was the only natural influence that accounted for some variability in any of the 3 seagrass structural descriptors ( $c a .11 \%$ of the total variation in the change of seagrass cover between 2003 and 2012). The erosion in seagrass structural attributes between 2003 and 2012 was significantly explained by the total number of impacts within a $500-\mathrm{m}$ radius at each seagrass meadow (Fig. 5). Regression coefficients from simple linear regressions were negative for the 3 seagrass structural descriptors, therefore suggesting a positive relationship between the erosion (i.e. loss) in meadow structural attributes between 2003 and 2012 and the number of these human-mediated impacts.

\section{Discussion}

Changes in the structure of Cymodocea nodosa seagrass meadows at Gran Canaria Island in the last decade have been spatially heterogeneous; some meadows (ca. 60\%) have clearly declined, whereas other meadows (ca. 40\%) seem to have remained unaltered. At present, it is difficult to explain the exact reasons underlying the local changes (or lack of) in the structure of this habitat, including a variety of human actions that can cause environmental impacts of different origin and intensities, overlapping across time and space (Halpern et al., 2008). Seagrass meadows are, moreover, naturally present as irregular patches because of the hydrodynamic conditions; this is particularly relevant in coasts open to large oceanic swells, e.g. the Canarian Archipelago. However, our study has demonstrated that an increase in the severity (number) of storms cannot be invoked to explain declines in C. nodosa meadows. Additionally, temporal fluctuations in other natural influences (here, SST, Chl- $a$ concentration and PAR light) does not seem to significantly contribute to explain variation in seagrass structural attributes between 2003 and 2012. Rather, our study points out that the decline of seagrass structural descriptors is, at least partially, explained by a variety of human-related actions operating at local scales. Despite some works identify global processes to explain seagrass decline (Jordá et al., 2012), many studies 
Table 3

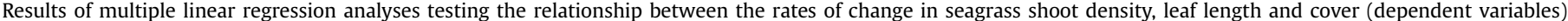

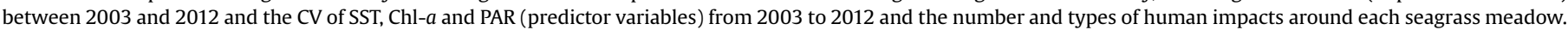

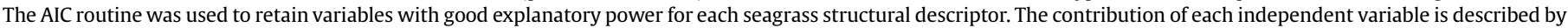
means of partial $r^{2}$ values, and $p$-values provide significance diagnoses.

\begin{tabular}{|c|c|c|c|c|c|}
\hline Shoot density & & Leaf length & & Seagrass cover & \\
\hline $\begin{array}{l}X_{1}=\text { number of outfalls }(p=0.006) \\
X_{2}=\text { number of run-off points }(p=0.006)\end{array}$ & $\begin{array}{l}r^{2}=0.2293 \\
r^{2}=0.1439\end{array}$ & $\begin{array}{l}X_{1}=\text { number of outfalls }(p=0.001) \\
X_{2}=\text { number of fish farms }(p=0.035)\end{array}$ & $\begin{array}{l}r^{2}=0.3324 \\
r^{2}=0.0703\end{array}$ & $\begin{array}{l}X_{1}=\text { number of ports }(p=0.004) \\
X_{2}=\text { CV of PAR }(p=0.017)\end{array}$ & $\begin{array}{l}r^{2}=0.1892 \\
r^{2}=0.1161\end{array}$ \\
\hline
\end{tabular}

show that declines are the result of accumulating impacts at local scales (González Correa et al., 2007). Our data adds up to this last body of research and so point towards the notion that a better management of the coast is irremediably necessary (Boudouresque et al., 2009).

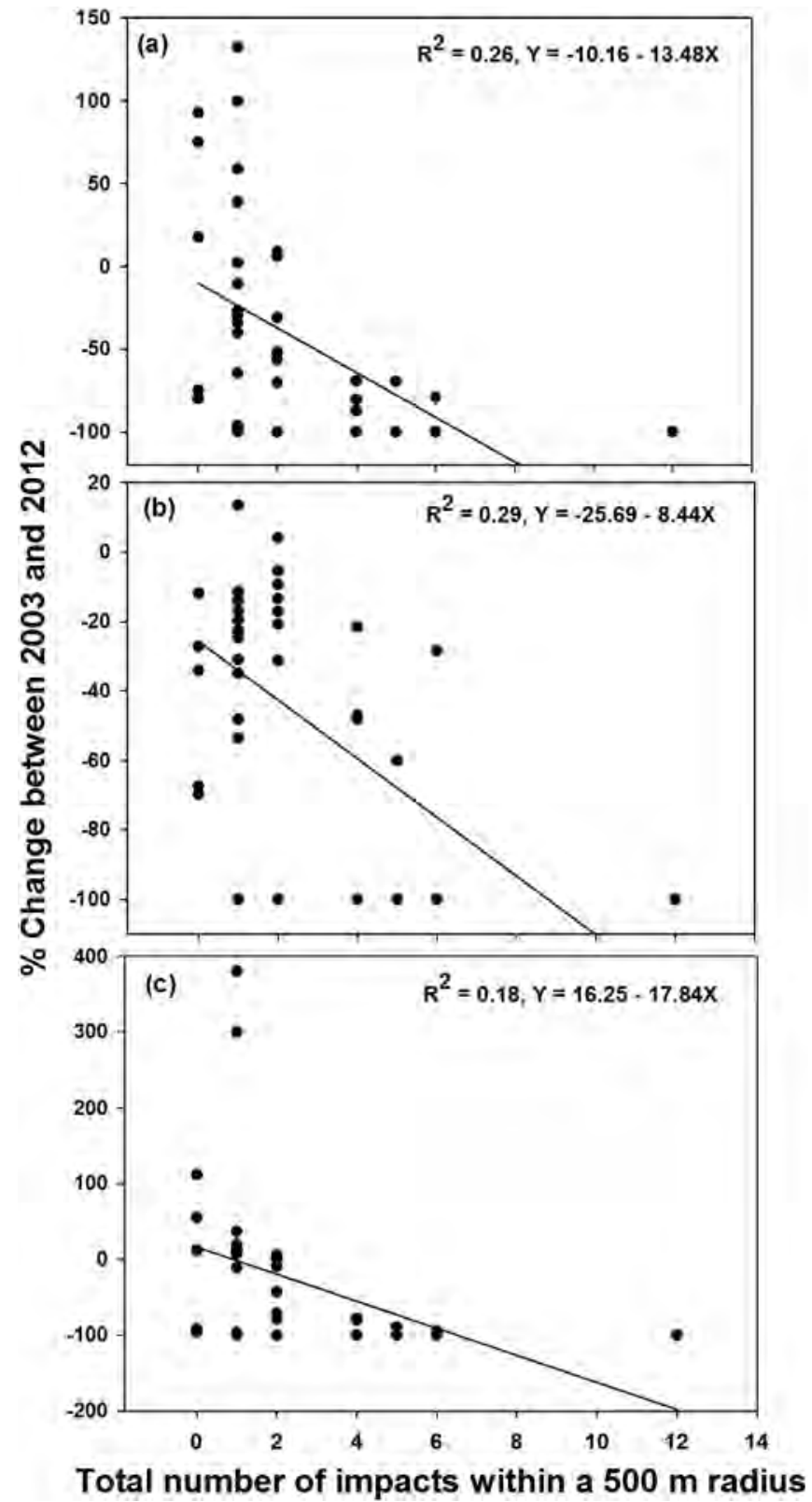

Fig. 5. Relationship between changes in seagrass (a) shoot density, (b) leaf length and (c) cover between 2003 and 2012 (expressed as percentage change relative to 2003 values; a positive value denotes an increase while a negative value denotes a decrease) and the total number of sources of impacts within a 500-m radius of each seagrass meadow.
Gran Canaria Island host 852,225 inhabitants; $87 \%$ of the population is located along the littoral perimeter, giving a population density of 3142 ind $\mathrm{km}^{-1}$ of the coast. In addition, about 3,000,000 tourists visit the island every year (www.gobiernodecanarias.org/ istac/temas_estadisticos/demografia). Obviously, this implies an enormous environmental pressure on the coast, as reported for other areas with a large tourism industry on the coast such as the Mediterranean Sea (Meinesz et al., 1991), where the proliferation of urban and industrial structures in the coast has inevitably fragmented and destroyed seagrass meadows (Montefalcone et al., 2007). For example, the number of outfalls has increased in the coast of Gran Canaria Island from 105 (2003) to 154 (2012), what give rise to 0.65 outfalls $\mathrm{km}^{-1}$ of coastal perimeter between 0 and $30 \mathrm{~m}$ depth, i.e. the bathymetric distribution of Cymodocea nodosa. Importantly, only $c a$. $20 \%$ of outfalls are authorized by the regional administration (Environmental Agency), while the rest are without any management (Viceconsejería de Medio Ambiente, 2008).

The most important discharges through outfalls are urban wastewaters (ca. $47.4 \%$ of total outfalls). There are, however, no accurate data on the exact volume and characteristics of urban wastewaters released into the sea at Gran Canaria. It is estimated that $c a .42,191 \mathrm{~m}^{3}$ day $^{-1}$ are released into the sea after a primary treatment, and $c a .60,273 \mathrm{~m}^{3}$ day $^{-1}$ after a secondary treatment (Consejo Insular de Aguas de Gran Canaria, 2013). At the moment, the number of wastewater treatment plants and the types of treatments seem insufficient; this implies that 'black waters' are released into the sea at $c a$. $\mathrm{DBO}_{5}$ of $700 \mathrm{mg} \mathrm{l}^{-1}, \mathrm{ca} .600 \mathrm{mg} \mathrm{l}^{-1}$ of suspended solids and ca. $30 \mathrm{mg} \mathrm{l}^{-1}$ of total $\mathrm{N}$ (Viceconsejería de Medio Ambiente, 2008). This has already caused severe disturbances on coastal areas of Gran Canaria, as a result of chronic eutrophication events (O'Shanahan et al., 2003; Ojeda and O'Shanahan, 2005). Several studies have demonstrated that wastewater discharges negatively affect seagrass abundance and performance (Lapointe et al., 1994; Cabaço et al., 2008). The negative effects of water-column fertilization on the fitness of Cymodocea nodosa have been recently experimentally demonstrated at Gran Canaria, where elevated nutrients enhance epiphytes growth and favours herbivore grazing (Tuya et al., 2013c). This evidence is in agreement with our results, suggesting that the number of outfalls of urban wastewater cause a decline of seagrass shoot density and leaf length. This type of impact, however, did not explain changes in seagrass cover, possibly because outfalls have been functioning for a long time before 2003. Sewage outfalls are, moreover, a source of inorganic $\mathrm{N}$ and $\mathrm{P}$ that may promote cyanobacteria blooms in subtropical areas, particularly during months of high temperatures (O'Neil et al., 2012). In the last years, blooms of the cyanobacteria Lyngbya spp. have been frequently observed in seagrasses of the south of Gran Canaria and Fuerteventura and Lanzarote as well (http://www.redpromar.com/fans). Lyngbya spp. is considered as a major threat for seagrasses due to its epiphytic growth on seagrass leaves and the production of allopathic substances (O'Neil et al., 2012). Hence, negative interactions between $C$. nodosa and Lyngbya spp. should be considered with caution, particularly within the framework of eutrophized environments. 
Adding to urban wastewater outfalls, brine discharges represent $\mathrm{ca}$. 23.4\% of the total number of outfalls off Gran Canaria Island. The increasing demand of freshwater for agriculture, tourism and local population has resulted in the construction of several desalination plants; the production capacity has increased from $\mathrm{ca}$. $151,170 \mathrm{~m}^{3}$ freshwater day ${ }^{-1}$ (2003) to $\mathrm{ca} .271,000 \mathrm{~m}^{3}$ freshwater day $^{-1}$ (2011) (Consejo Insular de Aguas de Gran Canaria, 2013). These desalination plants are dispersed along the littoral and have between 45 and $50 \%$ of efficiency; this implies that ca. 250,000$330,000 \mathrm{~m}^{3}$ day $^{-1}$ of brine (at 60-70 PSU) is discharged back into the ocean. The impact of brine discharges on seagrasses is well known, particularly over Cymodocea nodosa in the Mediterranean Sea (Palomar and Losada, 2010; Pagès et al., 2011; Fernández-Torquemada and Sánchez-Lisazo, 2011) and the Canary Islands (Portillo et al., 2013).

Coastal infrastructures, e.g. ports, marinas, breakwaters, piers, artificial beaches, are another type of anthropogenic impacts that may directly, or indirectly, alter seagrasses (Boudouresque et al., 2009), inducing both direct (e.g. burial and uprooting) and indirect (e.g. increased turbidity, epibiota development) seagrass deterioration. Ports and marinas may alter seagrass meadows during construction (Tuya et al., 2002) and associated dredging operations, as well as during operational stages (Ruiz and Romero, 2003; García, 2011; Grifoll et al., 2011). In Gran Canaria, for example, consistent differences in nutrient concentrations, chlorophyll- $a$ and the abundance of phytoplankton between the inner part, adjacent and open waters have been found at some ports (García, 2011). Actually, there are 27 coastal infrastructures around the island perimeter of Gran Canaria. The majority was constructed before 2003, except the Arinaga industrial port, which was constructed between 1998 and 2003. During the erection of the port, fine sediments were released, creating large plumes that drift up and down the coast according to semidiurnal tidal regimes, up to $5 \mathrm{~km}$ from the construction site (F. Espino, pers. obs.). Most likely, plumes increased turbidity and mechanical abrasion over plants. The two meadows directly affected by construction of this port (Arinaga and Formas, Fig. 1) had a cover of ca. 261,550 and $255,324 \mathrm{~m}^{2}$, and maximum shoot densities of $c a .1368 \pm 112.9$ and $1490 \pm 54.7$ shoots $\mathrm{m}^{-2}$ (mean $\pm \mathrm{SE}$ ), respectively, before the construction of the port (Espino et al., 2003). Afterwards, a progressive fragmentation of these meadows was observed (Monterroso et al., 2006), while the green rhizophytic algae Caulerpa prolifera (Forsskäl) Lamouroux and Caulerpa racemosa (Forsskäl) J. Agardh proliferated on bottoms previously dominated by Cymodocea nodosa. Recently, Tuya et al. (2013b) found a severe regression of Arinaga meadow, and demonstrated the negative interaction between $C$. prolifera and $C$. nodosa, where the green algae outcompete with the phanerogam, taking advantage of water quality deterioration. In 2012, we have found that the meadow at Formas has totally disappeared, while the seagrasses has been substituted by $C$. racemosa. Replacement of native seagrass species by green rhizophytic algae has been widely described, e.g. in the Mediterranean Sea (Montefalcone et al., 2006, 2007; Montefalcone, 2009).

Another factor explaining some variation of seagrass shoot density through time was sediment run-off. Gran Canaria is a semicircular island with a network of radial gullies. During heavy rainfall events, tonnes of sediments are released onshore, potentially affecting seagrass meadows adjacent to discharge points. Sediment run-off increases turbidity and promote light reduction, increase nutrients loads and growth of epiphytes, as well as oversedimentation, siltation and erosion (Airoldi and Beck, 2007).

In the Mediterranean, Posidonia oceanica is an endemic, slowgrowing, species that is substituted by Cymodocea nodosa when disturbances take place; $C$. nodosa is somehow considered a pioneer and opportunistic, fast-growing, species (Cancemi et al.,
2002; Montefalcone et al., 2006, 2007). In the Canary Islands, however, $C$. nodosa is the climax vegetated species on soft bottoms, and the only seagrass that forms extensive meadows in the subtidal (Reyes et al., 1995a). Our results point out, however, towards the notion that $C$. nodosa is sensitive to a range of human-induced impacts. In this context, we have demonstrated that decreases in the structure of $C$. nodosa-dominated meadows are connected with proximity, number and type of anthropogenic impacts. Of course, our work is merely correlative and so experimental studies should provide insight into the effects of multiple stressors (e.g. Tuya et al., 2013b; Tuya et al., 2013c). It has been suggested that seagrass regression and further disappearance often occur, at regional scales, over temporal scales ranging from 10 s to 100 s of years (Airoldi and Beck, 2007). Our results point out a severe decay in the structure of C. nodosa in exclusively 9 years. However, the changes in the structure of seagrass meadows have been heterogeneous, what points out at local, rather than at island-scale processes, as determinants of temporal changes. This study highlights the urgent need of actions to evaluate the conservation status of remaining C. nodosa meadows in the Canary Islands, as well as promoting urgent management actions to conserve and monitor meadows constituted by $C$. nodosa at the study region through efficient management of local impacts.

\section{Authors' contributions}

FT, RH and FE conceived the study. FT and FE designed the sampling strategy. Field work was performed by FT and FE. LRL and NAC performed the wave data analysis. JC performed the extraction of environmental data from satellite images and associated graphical output. FT performed statistical analyses. FT and RH managed projects associated with data collection. FT and FE wrote the paper. All authors contributed to readjustments on previous drafts.

\section{Acknowledgements}

Financial support of this study was partially provided within the framework of the project GESMAR (PCT-MAC 2007-2013) in close liaison with the local administration Cabildo de Gran Canaria, and the SEGA Program of Viceconsejería de Medio Ambiente in 2003. The research staff of ULPGC was partially supported by the Campus Atlántico Tricontinental. We would like to thank M. Garrido, R. Herrera, and O. Tavío for assisting during field collections in 2003 and H. Hernandez-Zerpa, M. Ramírez and T. Sánchez for assisting in 2012. We thank O. Bergasa for technical assistance with environmental data and A.J. González-Ramos for satellite data. Satellite data were freely available at Ocean Colour Web (NASA Goddard Space Flight Centre). F. Tuya was supported by the MINECO 'Ramón y Cajal' program. Wave data was kindly provided by 'Puertos del Estado'.

\section{Appendix A. Supplementary data}

Supplementary data related to this article can be found at http:// dx.doi.org/10.1016/j.ecss.2013.11.026.

\section{References}

Airoldi, L., Beck, M.W., 2007. Loss, status and trends for coastal marine habitats of Europe. Oceanogr. Mar. Biol. Ann. Rev. 35, 345-405.

Alberto, F., Arnaud-Haond, S., Duarte, C.M., Serrâo, E.A., 2006. Genetic diversity of a clonal angiosperm near its range limit: the case of Cymodocea nodosa at the Canary Islands. Mar. Ecol. Prog. Ser. 309, 117-129.

Anderson, M.J., 2001. A new method for non-parametric multivariate analysis of variance. Aust. Ecol. 26, 32-46. 
Anderson, M.J., Legendre, P., 1999. An empirical comparison of permutation methods for tests of partial regression coefficients in a linear model. J. Stat. Comput. Simul. 62, 271-303.

Barberá, C., Tuya, F., Boyra, A., Sánchez-Jerez, P., Blanch, I., Haroun, R., 2005. Spatial variation in the structural parameters of Cymodocea nodosa seagrass meadows in the Canary Islands: a multiscaled approach. Bot. Mar. 48, 122-126.

Boudouresque, C.F., Bernard, G., Pergent, G., Shili, A., Verlaque, M., 2009. Regression of Mediterranean seagrasses caused by natural processes and anthropogenic disturbances and stress: a critical review. Bot. Mar. 52, 395-418.

Cabaço, S., Machás, R., Vieira, V., Santos, R., 2008. Impacts of urban wastewater discharge on seagrass meadows (Zostera noltii). Estuar. Coast. Shelf Sci. 78, 1-13.

Cabaço, S., Ferreira, O., Santos, R., 2010. Population dynamics of the seagrass Cymodocea nodosa in Ria Formosa lagoon following inlet artificial relocation. Estuar. Coast. Shelf Sci. 87, 510-516.

Cancemi, G., Buia, M.C., Mazzella, L., 2002. Structure and growth dynamics of Cymodocea nodosa meadows. Sci. Mar. 66, 365-373.

Consejo Insular de Aguas de Gran Canaria, 2013. www.aguasdegrancanaria.com/.

Cunha, A.H., Araújo, A., 2009. New distribution limits of seagrass beds in West Africa. J. Biogeogr. 36, 1621-1622.

Duarte, C.M., Middelburg, J., Caraco, N., 2005. Major role of marine vegetation on the oceanic carbon cycle. Biogeosciences 2, 1-8.

Duarte, C.M., Dennison, W.C., Orth, R.J., Carruthers, T.J.B., 2008. The charisma of coastal ecosystems. Estuar. Coast. 31, 233-238.

Espino, F., Garrido, M., Herrera, R., Tavío, O., 2003. Seguimiento de especies amenazadas (Programa SEGA). Cymodocea nodosa Gran Canaria. Informe Técnico de la Viceconsejería de Medio Ambiente, Gobierno de Canarias.

Espino, F., Tuya, F., Brito, A., Haroun, R., 2011a. Ichthyofauna associated with Cymodocea nodosa meadows in the Canarian Archipelago (central-eastern Atlantic): community structure and nursery role. Cienc. Mar. 37, 157-174.

Espino, F. Tuya, F., Brito, A., Haroun, R., 2011b. Spatial variability in the structure of the ichthyofauna associated with Cymodocea nodosa seagrass meadows across the Canary Islands, north-eastern subtropical Atlantic. Rev. Biol. Mar. Oceanogr. 46, 391-403.

Fernández-Torquemada, Y., Sánchez-Lisazo, J.L., 2011. Response of two Mediterranean seagrasses to experimental changes in salinity. Hydrobiologia 669, 21-33.

García, A.P., 2011. Evaluación ambiental de las aguas costeras y puertos deportivos a partir de la comunidad fitoplanctónica en las islas Canarias, España. Ph.D. Thesis. Faculty of Marine Sciences. University of Las Palmas de Gran Canaria. Unpublished.

González Correa, J.M., Bayle, J.T., Sánchez Jerez, P., Valle, C., 2007. Posidonia oceanica meadows are not declining globally. Analysis of population dynamics in marine protected areas of the Mediterranean Sea. Mar. Ecol. Prog. Ser. 336, 111-119.

Grifoll, M., Jordá, G., Espino, M., Romo, J., García-Sotillo, M., 2011. A management system for accidental water pollution risk in a harbor: the Barcelona case study. J. Mar. Sys. 88, 60-73.

Halpern, B.S., Walbridge, S., Selkoe, K.A., Kappel, C.V., et al., 2008. A global map of human impact on marine ecosystems. Science 319, 948-952.

Hemminga, M., Duarte, C.M., 2000. Seagrass Ecology. Cambridge University Press, Cambridge, United Kingdom, p. 431.

Hughes, A.R., Williams, S.L., Duarte, C.M., Heck, K.L., Waycott, M., 2009. Associations of concern: declining seagrasses and threatened dependent species. Front. Ecol. Environ. 7, 242-246.

Infantes, E., Orfila, A., Bouma, T.J., Simarro, G., Terrados, J., 2011. Posidonia oceanica and Cymodocea nodosa seedling tolerance to wave exposure. Limnol. Oceanogr 56, 2223-2232.

Jordá, G., Marbà, N., Duarte, C., 2012. Mediterranean seagrass vulnerable to regional climate warming. Nat. Clim. Change 2, 821-824.

Lapointe, B.E., Tomasko, D.A., Matzie, W.R., 1994. Eutrophication and trophic state classification of seagrass communities in the Florida Keys. Bull. Mar. Sci. 54 696-717.

Mascaró, O., Oliva, O., Pérez, M., Romero, J., 2009. Spatial variability in ecological attributes of the seagrass Cymodocea nodosa. Botán. Marina 52 ,429-438.

Meinesz, A., Lefevre, J.R., Astier, J.M., 1991. Impact of coastal development on the infralittoral zone along the southeastern Mediterranean shore of continental France. Mar. Pollut. Bull. 23, 343-347.

Montefalcone, M., 2009. Ecosystem health assessment using the Mediterranean seagrass Posidonia oceanica: a review. Ecolog. Indic. 9, 595-604.

Montefalcone, M., Albertelli, G., Bianchi, C.N., Mariani, M., Morri, C., 2006. A new synthetic index and a protocol for monitoring the status of Posidonia oceanica meadows: a case study at San Remo (Ligurian Sea, NW Mediterranean). Aqua. Conserv. Mar. Freshw. Ecosys. 16, 29-42.

Montefalcone, M. Morri, C, Peirano, A, Albertelli, G, Bianchi, CN, 2007. Substitution and phase shift within the Posidonia oceanica meadows of NW Mediterranean Sea. Estuar. Coast. Shelf Sci. 75, 63-71.

Monterroso, O., Rodríguez, M., Riera, R., Ramos, E., 2006. Influencia de la ampliación del Puerto de Arinaga sobre las comunidades marinas. CIMA-Informe Técnico 8.

Morel, A., Huot, Y., Gentili, B., Werdell, P.J., Hooker, S.B., Franz, B.A., 2007. Examining the consistency of products derived from various ocean color sensors in open ocean (case 1) waters in the perspective of a multi-sensor approach. Remote Sens. Environ. 111, 69-88.
O’Shanahan, L., Vela, E., Sánchez, A., 2003. Efectos de un vertido de aguas residuales sobre una comunidad bentónica del litoral de Telde, NE de Gran Canaria (Islas Canarias). Vieraea 31, 253-266.

Ojeda, A., O'Shanahan, L., 2005. Discoloraciones por acumulaciones de la diatomea bentónica epipsámica Attheya armatus (Centrales, Bacillariophyta) en playas de arena del S y SW de Gran Canaria (Canarias, España). Vieraea 33, 51-58.

Orth, R.J., Carruthers, T.J.B., Dennison, W.C., Duarte, C.M., Fourqurean, J.W., Heck Jr., K.L., Hughes, A.R., Kendrick, G.A., Kenworthy, W.J., Olyarnik, S., Short, F.T., Waycott, M., Williams, S.L., 2006. A global crisis for seagrass ecosystems. BioScience 56, 987-996.

O'Neil, J.M., Davis, T.W., Burford, M.A., Gobler, C.J., 2012. The rise of harmful cyanobacteria blooms: the potential roles of eutrophication and climate change. Harmful Algae 14, 313-334.

Pagès, J.F., Pérez, M., Romero, J., 2011. Sensitivity of the seagrass Cymodocea nodosa to hypersaline conditions: a microcosm approach. J. Exp. Mar. Biol. Ecol. 386, 34-38.

Palomar, P., Losada, I.J., 2010. Desalination in Spain: recent developments and recommendations. Desalination 255, 97-106.

Pavón-Salas, N., Herrera, R., Hernández-Guerra, A., Haroun, R., 2000. Distributional pattern of seagrasses in the Canary Islands (Central-East Atlantic Ocean). J. Coast. Res. 16, 329-335.

Pergent-Martini, C., Boudouresque, C.F., Pasqualini, V., Pergent, G., 2006. Impact of fish farming facilities on Posidonia oceanica meadows: a review. Mar. Ecol. 27, 310-319.

Portillo, E., Louzara, G., Ruiz de la Rosa, M., Quesada, J., González, J.C., Roque, F., Antequera, M., Mendoza, H., 2013. Venturi diffusers as enhancing devices for the dilution processes in desalination plant brine discharges. Desalin. Water Treat. 51, 525-542.

Reyes, J., Sansón, M., 1997. Temporal distribution and reproductive phenology of the epiphytes on Cymodocea nodosa leaves in the Canary Islands. Bot. Mar. 40, 193-201.

Reyes, J., Sansón, M., Afonso-Carrillo, J., 1995a. Distribution and reproductive phenology of the seagrass Cymodocea nodosa (Ucria) Ascherson in the Canary Islands. Aquat. Bot. 50, 171-180.

Reyes, J., Sansón, M., Afonso-Carrillo, J., 1995b. Leaf phenology, growth and production of the seagrass Cymodocea nodosa at El Médano (South of Tenerife, Canary Islands). Bot. Mar. 38, 457-465.

Ruiz, J.M., Romero, J., 2003. Effects of disturbances caused by coastal construction on spatial structure, growth dynamics and photosynthesis of the seagrass Posidonia oceanica. Mar. Pollut. Bull. 46, 1523-1533.

Short, F.T., Polidoro, B., Livingstone, S.R., Carpenter, K.E., Bandeira, S., Bujang, J.S., Calumpong, H.P., Carruthers, T.J.B., Coles, R.G., Dennison, W.C., Erftemeijer, P.L.A., Fortes, M.D., Freeman, A.S., Jagtap, T.G., Kamal, A.H.M., Kendrick, G.A., Kenworthy, W.J., La Nafie, Y.A., Nasution, I.M., Orth, R.J., Prathep, A., Sanciangco, J.C., van Tussenbroek, B., Vergara, S.G., Waycott, M., Zieman, J.C., 2011. Extinction risk assessment of the world's seagrass species. Biol. Conserv. 144, 1961-1971.

Smale, D.A., Wernberg, T., 2009. Satellite-derived SST data as a proxy for water temperature in nearshore benthic ecology. Mar. Ecol. Prog. Ser. 387, 27-37.

Terrados, J., Ros, J.D., 1993. Limitación por nutrientes del crecimiento de Cymodocea nodosa (Ucria) Ascherson en sedimentos carbonatados en el Mar Menor, Murcia, SE de España, vol. 11. Publicaciones Especiales del Instituto Español de Oceanografía, pp. 9-14.

Tuya, F., Pérez, J., Medina, L., Luque, A., 2001. Seasonal variation of the macrofauna from three seagrass meadows of Cymodocea nodosa off Gran Canaria (CentralEastern Atlantic Ocean). Cienc. Mar. 27, 223-234.

Tuya, F., Martín, J.A., Luque, A., 2002. Impact of a marina construction on seagrass bed at Lanzarote (Canary Islands). J. Coast. Conserv. 8, 157-162.

Tuya, F., Martín, J.A., Luque, A., 2006. Seasonal cycle of a Cymodocea nodosa seagrass meadow and associated ichthyofauna at Playa Dorada (Lanzarote, Canary Islands, eastern Atlantic). Cienc. Mar. 32, 695-704.

Tuya, F., Espino, F., Terrados, J., 2013a. Preservation of seagrass clonal integration buffers against burial stress. J. Exp. Mar. Biol. Ecol. 439, 42-46.

Tuya, F., Viera-Rodríguez, M.A., Guedes, R., Espino, F., Haroun, R., Terrados, J., 2013c. Seagrass responses to nutrient enrichment depend on clonal integration, but not flow-on effects on associated biota. Mar. Ecol. Prog. Ser. 490, 23-35.

Tuya, F., Hernández-Zerpa, H., Espino, F., Haroun, R., 2013b. Drastic decadal decline of the seagrass Cymodocea nodosa at Gran Canaria (eastern Atlantic): interactions with the green algae Caulerpa prolifera. Aquat. Bot. 105, 1-6.

Viceconsejería de Medio Ambiente, 2008. Censo Oficial de Vertidos. Gobierno de Canarias. www.idecan.grafcan.es/idecan/.

Waycott, M. Duarte C.M., Carruthers, TJB, Orth, RJ. Dennison, WC. Olyarnik, S. Calladine, A., Fourqurean, J.W., Heck Jr., K.L., Hughes, A.R., Kendrick, G.A., Kenworthy, W.J., Short, F.T., Williams, S.L., 2009. Accelerating loss of seagrasses across the globe threatens coastal ecosystems. Proc. Natl. Acad. Sci. U S A 106, 12377-12381.

Wright, J.P., Jones, C.G., 2006. The concept of organisms as ecosystem engineers ten years on: progress, limitations, and challenges. Bioscience 56, 203-209. 